\title{
THE LAWYER IN THE REGULATORY PROCESS
}

\author{
C. KEMM YATES*
}

\begin{abstract}
This paper considers the role of the lawyer in the regulatory process with particular reference to the National Energy Board and the Alberta Energy Resources Conservation Board. The current function of lawyers as counsel to participants and to tribunals and as tribunal members is examined. Weaknesses in the current role are identified, arising from such matters as the use of extrinsic evidence and political influences upon tribunals. The paper concludes with suggestions for regulatory reform.
\end{abstract}

\section{INTRODUCTION}

"Dick (the butcher): The first thing we do, let's kill all the lawyers.

Jack Cade (a rebel): Nay, that I mean to do."

Shakespeare, Henry VI, Part II, Act IV, Scene II

The conversation between Jack Cade and one of his followers was first performed in 1592, but it is the type of discussion which could be taking place today amongst politicians, members of regulatory boards and their staffs, or persons involved in the oil and gas industry who have contact with the regulatory process. With increasing frequency, the view is expressed that the participation of lawyers in the regulatory process hampers effective administration and speedy decision-making while contributing substantially to delay and expense. Elimination of lawyers is advocated in the name of efficiency.

It is generally acknowledged that the original reasons for the creation of tribunals included the apparent inappropriateness of courts to decide technically complex issues in a rapidly expanding and complicated society, the perceived necessity for particular expertise in dealing with such issues, and the requirement of speed of administration. It was felt that legally trained judges would lack the background and knowledge to determine issues involving technical questions, and that the court process (which by definition includes cross-examination by counsel) would be too slow and ponderous to meet the requirements of administrative efficiency. The result was the establishment of an extra-curial system of administrative tribunals, but there still remains an often expressed fear that over-judicialization of the hearing process will defeat its purpose. It has been suggested that effective participation by lawyers encumbers the regulatory process with lawyers' values rather than civil servants' values, and that this is an undesirable development.' It is true that the lawyer is by nature, training, and experience concerned with protection of the individual rather than the larger interests of the state. His training in the common law imbues him with an appreciation of fairness and a respect for precedent that makes him suspicious of any departures from the time-proven procedures of the adversarial system. He emphasizes the importance of legal safeguards and doubts the existence of fair-minded civil servants making equitable decisions in the absence of full disclosure. He places little credence in the suggestion that efficacious safeguards lie

- Barrister and Solicitor, Fenerty, Robertson, Prowse, Fraser and Hatch, Calgary, Alberta

1. J. Willis, "The McRuer Report: Lawyers; Values and Civil Servants' Values"(1968) $18 U$. T.L.J. 351 . 
in a vigilant press and a "watch that government" atmosphere in the general public. ${ }^{2}$ These attitudes are considered to be inappropriate in the regulatory process, since tribunals are seen by most commentators as part of the administrative machinery of government rather than as part of the judicial system.

The thesis of this paper is that it is incorrect to view the effective application of lawyers' biases and methods to the regulatory process as causing inefficiency and detriment to the system. There may be some delay, but that is a small price to pay for fairness in administration. ${ }^{3}$ The main issue is the reconciliation of procedural justice with effective government. ${ }^{4}$ How can a balance be reached between the need to maintain efficiency in the administrative process and the need to ensure that participants are not harmed or seen to be harmed by the absence of procedural safeguards like those governing courts of law ${ }^{5} \mathrm{~A}$ major concern today is that participation by lawyers has resulted in tipping the balance towards procedural justice at the expense of efficiency. This concern is most often expressed by non-lawyers who feel that the inefficiency is the result of "over-judicialization". However, they overlook the fact that "over-politicization" is the real problem. Many regulatory hearings are replete with judicial trappings (such as cross-examination and final argument) which contribute substantially to the time and expense involved. But the cost in terms of time and expense would be insignificant if the proceedings were an effective element in the decision-making process. In fact, the over-politicization of the system has resulted in administrative decisions being made outside the hearing room, frequently on the basis of information or political directives that never appear in the hearing transcript. This is the ultimate inefficiency since it renders much of the hearing process superfluous.

The Shakespearean quotation with which this paper commenced is somewhat misleading. In their proper context, the words indicate that Shakespeare was very much aware that a totalitarian form of government could not be created unless lawyers were eliminated. Today, an element of totalitarianism has been created in the regulatory process by permitting some decisions to become completely political. Lawyers play a role in the process, but they are being misused - their participation merely adds a facade of impartiality to what is in fact often a political decision. Lawyers can and should play a valuable and effective role in the regulatory process to ensure that there is actual and apparent fairness to participants. To achieve this a number of modifications to the current system are required. This paper suggests what the role of law yers should be in the regulatory process. Of necessity, the present role is described.

2. For a detailed discussion of this issue, see Willis, id See also B. Schon, Beyond the Stable State (1971) Chapter 6 cited in G. Bruce Doern, "Introduction: The Regulatory Process in Canada", The Regulatory Process in Canada (1978) 24.

3. See H. Whitmore, "The Role of the Lawyer in Administrative Justice" (1970) 33 Mod. $L$. Rev. 481.

4. Ontario Royal Commission Enquiry into Civil Rights. Report No. 1. (Commissioner: Honourable J.C. McRuer 1968) 207.

5. G. La Forest and G. Watkins, "The Impact on Federal Administrative Tribunals of Recent Developments in Administrative Law", in The Conduct of Hearings by Federal Administrative Agencies, edited proceedings from the program held in Ottawa on June 23, 1976, Law Society of Upper Canada, 18. 
No reference is made to judicial review of administrative action (the apparent passion of law teachers and judges) or to any political role that might be played by lawyers. Consideration is restricted to the particular role of lawyers in the hearing process itself, as exemplified in hearings of the two most important energy boards - the National Energy Board (hereinafter also referred to as "NEB" or "the Board") and the Alberta Energy Resources Conservation Board (hereinafter also referred to as "ERCB" or "the Board"). What is and what should be the role of the lawyer as counsel to participants in the hearing process of these tribunals, as counsel to the tribunals themselves, as members of the tribunals, or as representatives of the public interest?

\section{THE CURRENT ROLE OF LAWYERS}

\section{(A) National Energy Board}

The National Energy Board was established by a Conservative government as a reaction to the politically disastrous consequences of the Great Canadian Pipeline Debate of $19566^{\circ}$ That debate gave rise to the Gordon Commission ${ }^{7}$ which recommended the establishment of a national energy authority to advise government on matters related to long term energy requirements, and to regulate contracts for the export of oil, gas and electric power. Subsequently, the Borden Royal Commission ${ }^{8}$ was charged with the responsibility of assessing the national interest in respect to energy matters. Specifically, the Commission was to recommend the nature and extent of authority that might be conferred on a National Energy Board to administer aspects of energy policy, subject to the control and authority of Parliament. ${ }^{9}$ The result was the National Energy Board Act of $1959^{10}$ which establishes both advisory functions and adjudicative functions for the NEB. ${ }^{11}$ Lawyers participate as counsel in hearings held by the Board in the discharge of both of its functions.

In performing its advisory role, the Board is required to monitor and report to the Minister of Energy, Mines and Resources on virtually every important federal aspect of all energy resource development in the country. ${ }^{12}$ In order to do so, the NEB is empowered to conduct inquiries on its

6. For a more comprehensive historical background see I. McDougall, "The Canadian National Energy Board: Economic Jurisdiction in the National Interest or Symbolic Reassurance?" (1973) 11 Alta L. Rev., 327 at 329-338; A. Lucas and T. Bell, The National Energy Board: Policy, Procedure and Practice (Law Reform Commission of Canada 1977); A. Lucas, "The National Energy Board" in The Regulatory Process in Canada, supra n. 2, at 259 et seq.; B. Fisher, "The Role of the National Energy Board in Controlling the Export of Natural Gas from Canada" (1971) 9 Osg. Hall L.J., 553, 554-558; W. Kilborn, Pipeline: Trans Canada and the Great Debate, A History of Business and Politics (1970).

7. Canada. Royal Commission on Canada's Economic Prospects, FinalReport (1957).

8. Canada. Royal Commission on Energy, First Report (1958).

9. For specific terms of reference of the Borden Commission, see Order-in-Council P.C. 1957-1386.

10. National Energy Board Act, S.C. 1959 c. 46.

11. For a full discussion on the functions of the National Energy Board see A. Lucas, "The National Energy Board" found in The Regulatory Process in Canada, supra n. 2, 259 at 261 et. seq.; T. Bell, The National Energy Board-Policy, Procedure and Practice, supra n.6.

12. National Energy Board Act, R.S.C. 1970, c. N-6, Part II, especially s. 22. 
own motion. ${ }^{13}$ The adjudicative functions of the Board include exercising specific controls over the granting of certificates of public convenience and necessity for construction of pipelines and international power lines, ${ }^{14}$ the issuing of licences for the export and import of natural gas, oil and power ${ }^{15}$ and the approval of utility rates, tariffs and tolls. ${ }^{16}$ The NEB may hold a public hearing in relation to any matter if it considers it advisable to do so. Hearings in respect of certificates or licences must be public. ${ }^{17}$

The NEB Act itself contains little guidance on procedural matters. It does state that the NEB is a court of record ${ }^{18}$ with all of the powers, rights and privileges of a superior court of record in respect to matters necessary or proper for the due exercise of its jurisdiction. ${ }^{19}$ More importantly, it authorizes the Board to make rules respecting its sittings, ${ }^{20}$ the procedure for making applications, representations and complaints to the Board, and the conduct of hearings before the Board. ${ }^{21}$ The Board has promulgated rules $^{22}$ that delineate the role played by counsel at its hearings.

The Rules are most applicable to the adjudicative function of the Board, which is most frequently exercised in respect of an "application". The Act does not specifically require a company to make a formal application for a certificate of public convenience and necessity permitting construction of an interprovincial or international pipeline ${ }^{23}$ or for a licence to export or import any gas or oil. ${ }^{24}$ Similarly, there is no statutory requirement that application be made for approving a tariff. ${ }^{25}$ However, the Rules define "application" to include application for any of the three approvals previously mentioned. ${ }^{28}$ Those Rules provide that the application must be in writing, signed by the applicant or the applicant's solicitor, ${ }^{27}$ and set out in detail the information to be filed. ${ }^{28}$ The Board may direct that an application be heard and determined ex parte or may make an expedited proceedings order. ${ }^{29}$ Where it does neither, and if it also does not direct that the provisions of its Rules shall not apply, ${ }^{30}$ the Board is required to set the application down for hearing..$^{31}$ After notice, a respondent or in-

13. Id, ss. 11(b) and 14(c).

14. Id, Part III, Part V.

15. Id, Part VI.

16. Id, Part IV.

17. Id, s. 20.

18. Id, s. 10(1).

19. Id., s. 10(3).

20. Id. s. 7(a).

21. Id., s. 7(b).

22. Rules Relating to Practice and Procedure in Proceedings Before the National Energy Board, SOR/72-413.

23. National Energy Board Act, S.C. 1959 c. 46, s. 44.

24. Id, ss. 81 and 87; SOR/70-206.

25. Id., ss. 50 and 51 .

26. Supra n. 22, Rule 2(1)(c)(i), (xiii) and (iv).

27. Id, Rule 4(1).

28. Id., Rules $4(2)$ and 5 .

29. Id. Rules 5.2 - 5.4 .

30. Id, Rule 3(2).

31. Id, Rule 6(1). 
tervenor may file a written submission, signed by his solicitor or by himself, containing a concise statement of the facts from which the nature of the respondent's or the intervenor's interest in the proceeding may be determined. ${ }^{31}$ Issues of fact may be resolved before or during the course of the hearing ${ }^{33}$ and issues of law may be raised at any point in the proceedings. ${ }^{34}$ The Board may and does utilize a technique of pre-hearing conferences ${ }^{35}$ as well as information requests and responses.

The Board in fact holds public hearings on all "major" applications. ${ }^{36}$ Procedurally, the hearings are formal and similar in many ways to those of a court of law. This is not surprising since it has been held by at least one court that the word "hearing" in s. 20 is to be construed as analogous to and importing a "trial" before a court of law ${ }^{37}$ Evidence is taken under oath. Direct evidence, however, is often of the "canned" variety, prepared and distributed in advance. There is often additional direct evidence presented at the hearing but the method of adducing such evidence bears no relationship whatsoever to proceedings in a court of law. Parties are permitted to go through the charade of reading questions and answers into the record as "direct evidence". Usually witnesses are presented in panels of up to six persons to speak to the evidence; cross-examination by other parties and by the Board and Board counsel is permitted. Normally, each party is permitted to present arguments at the conclusion of the hearing.

Lawyers play a substantial procedural role as counsel to applicants or intervenors in the adjudicative hearings of the NEB. Law yers are usually involved in the preparation of the application or intervention to ensure that the material filed complies with the statutory requirements. Counsel also take part at the hearing in the filing of exhibits, the presentation of direct evidence, argument of any procedural or other motions, crossexamination and final argument. The role has developed to a similar state in hearings relating to the advisory function of the NEB, notwithstanding that no application exists and that there is supposedly no adjudication being made. The most recent example is the inquiry into Canadian natural gas supply and requirements in which full cross-examination and argument was permitted. ${ }^{38}$

A second role for lawyers in the current NEB hearing procedure is that of counsel to the Board. One of the seven branches of the Board's staff is the law branch. ${ }^{39}$ It currently consists of six lawyers who handle counsel work at hearings as well as opinions on issues arising in the course of routine regulation or ministerial advice. The law branch is consulted in

\footnotetext{
32. Id, Rule 7.

33. Id., Rule 11.

34. Id., Rule 12.

35. Id, Rule 13.

36. See A. Lucas, "The National Energy Board", in The Regulatory Process in Canada, supra n.2,259 at 282-288.

37. A.G. Manitobe v. National Energy Board and Dow Chemical of Canada Limited [1974]2 F.C. 502, 525(F.C.T.D.) per Cattanach, J.

38. Order Number GHR-1-78; National Energy Board, Canadian Natural Gas Supply Requirements (1979).

39. The others are administration, economics, electrical engineering, engineering, financial and oil policy.
} 
respect to the legal aspects of most issues, but there is now apparently somewhat less informal contact associated with the Board's advisory function that in previous years. ${ }^{40}$ The member of the law branch who acts as counsel in a particular hearing usually plays an active role throughout the application process. He provides advice during staff review of the application and preparation of questions for cross-examination. During the course of the hearing, he acts as counsel to the Board and advises the hearing panel on issues which might arise during the hearing. Since the Board staff do not present a case to the Board members, the Board counsel calls no evidence during the hearing but will normally cross-examine other parties. This cross-examination is usually restricted to clarification of issues or information or to obtaining additional information from the applicants. In the past, some Board lawyers have seen their role as somewhat more adversarial in nature, extending to extensive examination to ensure that an applicant meets the applicable statutory requirements. Normally, however, participation by Board counsel is restricted to asking the questions prepared in conjunction with the staff and apparently distributed in advance to the Board. It is always somewhat disconcerting to see the Board lawyer ask a question in crossexamination, receive an answer from a witness, then turn the page in his book of questions at the same time that all of the Board members are turning the same page in their books.

In recent years, no role has been played by lawyers as members of the National Energy Board. When N. J. Stewart moved from the Board to the Energy Allocation Board in 1973, the National Energy Board was left without a legally trained member." ${ }^{41}$ That situation remained until the appointment of Mme. L. M. Thur in March 1977. Byron Horner, appointed in April of this year, is also legally trained, but neither he nor Mme. Thur practiced energy law before their appointment to the NEB.

The National Energy Board does not appear to perceive any necessity to have the public interest represented in its hearings by separate counsel. This may be a result of the lenient approach to participation by intervenors, as most hearings will include representations from some public interest group. ${ }^{2}$ Further, the Board is itself charged with the responsibility of determining the "public interest"; ${ }^{43}$ so it may feel that it or Board counsel should determine the public interest and that appointment of other counsel could be construed as an abdication of that responsibility.

\section{(B.) Energy Resources Conservation Board}

Lawyers play similar procedural, roles in hearings of the Energy Resources Conservation Board. The ERCB and its predecessors have

40. A. Lucas, "The National Energy Board", in The Regulatory Process in Canada, supra n. 2,259 at 271 .

41. Id., fn. 55.

42. An example of this occurred recently when in June 1979 the NEB rejected the arguments advanced by Foothills Pipeline Ltd. that Progas Ltd. (a consortium of oil and gas producing companies) and the Canadian Arctic Resources Committee could not participate in a hearing relating to the rate of return applicable to the Pipeline.

43. At least in respect to ss. 44 and 22. 
always exercised adjudicative and advisory functions. ${ }^{4}$ Adjudicative jurisdiction arises in several statutes, but the advisory functions are now set forth in the Energy Resources Conservation Act. ${ }^{45}$ The ERCB may, and, at the request of the Lieutenant Governor in Council, shall, make enquiries and investigations and prepare studies and reports on any matter within the purview of any act administered by and related to energy resources and energy, and recommend to the Lieutenant Governor in Council such measures as it considers necessary or advisable in the public interest related to the exploration for, production, development, conservation, control, transportation, transmission, use and marketing of energy resources and energy. ${ }^{46}$ The Chairman of the Energy Resources Conservation Board is a member of the Energy Committee ${ }^{47}$ which is charged with the responsibility of advising the Lieutenant Governor in Council on policy matters concerned with the administration of Alberta's energy resources or energy..$^{18}$ In fact, the main purpose of the Board appears to be advisory, ${ }^{49}$ although its adjudicative functions have been expanding in recent years with the enactment of several statutes administered by the Board. ${ }^{50}$

Hearings seem to arise most frequently under The Pipeline Act 1975 (permits to construct pipelines), The Gas Resources Preservation Act (permits to export gas from Alberta; supply and demand inquiries) and The Oil and Gas Conservation Act (industrial development permits). In the conduct of its hearings, the ERCB is subject to The Administrative Procedures Act ${ }^{\text {s1 }}$ and is given the powers of a Commissioner appointed under the Public Inquiries Act (essentially those of a court in civil cases). ${ }^{52}$ The Rules of Practice of the Energy Resources Conservation Board ${ }^{53}$ set out the factual requirements for an application for an order, permit or approval ${ }^{54}$ as well as the requirements for interventions. ${ }^{55}$ There are specific rules relating to evidence receivable at a hearing. ${ }^{56}$ The Energy Resources Conservation Act expressly states that the ERCB is not bound by the rules of law concerning evidence applicable to judicial proceedings ${ }^{57}$ and the Board does not receive evidence under oath.

44. See The Oil \& Gas Conservation Act, 1938, S.A. 1938, c. 15, which initially set out ad. visory and adjudicative functions for the Petroleum and National Gas Conservation Board.

45. S.A. 1971, c. 30 .

46. Id., s. 24.

47. Id, s. 19.

48. Id. s. 21 .

49. Id., s. 2.

50. The ERCB has jurisdiction under The Oil and Gas Conservation Act, R.S.A. 1970, c. 267; The Pipeline Act, 1975, S.A. 1975, c. 30; The Gas Resources Preservation Act, R.S.A. 1970, c. 157; The Hydro and Electric Energy Act, S.A. 1971, c. 49; The Coal Conservation Act, S.A. 1973, c. 65; The Coal Mines Safety Act, S.A. 1974, c. 18; The Quarries Act, R.S.A. 1970, c. 305; The Turner Valley Unit Operations Act, R.S.A. 1970, c. 375.

51. R.S.A. 1970, c. 2; Alta. Reg. $123 / 70$.

52. Energy Resources Conservation Act. S.A. 1971, c. 30, s. 37. See also Public Inquiries Act, R.S.A.1970, c. 296.

53. Alta. Reg. $149 / 71$.

54. Id, Rule 7.

55. Id, Rules $12 \cdot 16$.

56. Id, Rules $21 \cdot 26$.

57. Energy Resources Conservation Act, S.A. 1971, c. 30, s. 30(2). 
The role of the lawyer as counsel to a participant in an ERCB hearing is essentially the same as in an NEB hearing. When appearing for the applicant or an intervenor, counsel must be cognizant of the statutory requirements of the application or intervention. He participates in the filing of exhibits and presentation of direct evidence, any procedural issues which arise during the course of the hearing, and cross-examination and argument. The goal is to present his client's case in a logical, understandable and expeditious fashion.

Counsel to the ERCB appears to play a similar role to counsel to the $\mathrm{Na}$ tional Energy Board. He advises the Board on legal matters and often performs an active role in the hearing process by questioning witnesses. He does not provide assistance to members of the public in presenting their views to the tribunal, although the ECRB has on at least one recent occasion engaged outside counsel to perform that role. ${ }^{58}$

Perhaps because of the technical advisory nature of the ERCB, there has never been a legally trained member of the Board. Almost all appointments (including five of the current seven members) have been made from within the organization, so lawyers have no role whatsoever as members of the tribunal.

\section{(C.) Effectiveness of the Current Role}

It is clear that lawyers currently play a substantial procedural role in the hearing process of the National Energy Board and the Energy Resources Conservation Board. However, it is equally clear that the role is almost completely restricted to participation as counsel to participants and to the tribunal. The appearance of lawyers at hearings lends an adversarial nature to the proceedings and creates an appearance of fairness, but that appearance is a facade unless the hearing is the determinative factor in the decision-making process of the tribunal. In situations where it is not the determinative factor, lawyers are being misused to give an air of impartiality to matters that are political in nature. This is often the case in the energy field. Consequently, a conflict arises between what might be the best political judgment to apply to a certain set of facts and what the result of a strictly judicial assessment would be. Evidence presented at a hearing through the efforts of the lawyers in examinationin-chief and cross-examination is often ignored. Since there are few lawyers, if any, on the applicable boards, the effect of cross-examination or presentation of evidence is frequently lost in any event. Decisions of the tribunals often seem to be made on the basis of evidence or political pressures outside the hearing room.

There is an effective role for lawyers to play in the hearing process to ensure fairness. For such fairness to exist, however, there should be proper presentation of evidence to the board, including meaningful crossexamination. The decision should be made on the basis of that evidence, not in response to matters extrinsic to the hearing. The guiding principle should be that evidence upon which the decision is made must be tested by cross-examination. If evidence is ignored or the decision is political, then the hearing itself is worthless and the role of lawyers as counsel is superfluous.

58. Application Number 770866 by Esso Resources, Canada, Limited, Cold Lake Project. 


\section{Rules of Evidence}

The provisions of the Energy Resources Conservation Act specifically state that the ERCB is not bound by the rules of law concerning evidence which are applicable to judicial proceedings. ${ }^{59}$ This may be merely a codification of the common law rule that a tribunal is not bound by the legal rules of evidence. ${ }^{60}$ The existence of the common law rule is probably the reason why the National Energy Board Act contains no statutory equivalent to s. 30(2) of the Energy Resources Conservation Act. In reviewing tribunal procedure, courts have generally permitted tribunals to avoid the strictness and formality of court procedures while ensuring a basic standard of fairness. ${ }^{61}$ Accordingly, tribunals may admit hearsay evidence or opinions and conclusions of witnesses and may also rely on reports of testimony as to facts without having before them the person who made the report or gave the testimony. ${ }^{62}$ In fact, there is specific provision in the National Energy Board Rules for admitting evidence taken at another hearing before the Board or at a hearing before any board, commission, or other competent tribunal of a province. ${ }^{63}$

It has been suggested that the imposition of restrictions on the admissibility of evidence in court while failing to impose the same restrictions on lesser administrative bodies having similar powers to make binding factual decisions illustrates greater confidence in the discretionary capacity of administrative agencies than in judges ${ }^{64}$ The reason for this may be that in court the factual matters requiring determination are nearly always disputed while in administrative matters the fact finding may or may not involve a disputed issue of fact; arguably, strict evidence rules may be relaxed where the adversarial nature of the inquiry is lacking. ${ }^{65}$ In fact, however, the rules of evidence are not applied even in hearings of an adjudicative nature which are just as adversarial as any trial.

The rules of evidence have definite advantages, not the least of which is that they are time proven. However, they are also very restrictive since they stem from an historical fear that juries which might be illiterate were incapable of differentiating between the probative values of different methods of proof. ${ }^{68} \mathrm{~A}$ regulatory board should have the power to adapt rules and procedures to its needs, but too much informality or licence could result in violation of the principles of natural justice. Even if the principles of fairness are followed in the course of admission of evidence at the hearing, the result is still unfair if the hearing evidence is ignored by the tribunal in reaching its ultimate decision.

59. Energy Resources Conservation Act, S.A. 1971, c. 30, s. 30(2).

60. See J. Kavanagh, A Guide to Judicial Review (1978) 18.

61. R. Reid and H. David, A dministrative Law and Practice (2nd ed., 1978) 75.

62. R. v. Deputy Industrial Injuries Commissioner [1965) 1 Q.B. 456; [1965] 1 All E.R. 81 (C.A.)

63. Rules Relating to Practice and Procedure in Proceedings Before the National Energy Board, SOR/72-413, Rule 18. This rule was created expressly for admission of evidence and reports of the ERCB. See A. Lucas, "The National Energy Board" in The Regulatory Process in Canada, supra n.2,259 at 311, fn. 134.

64. S. Gard, "Evidence in Administrative Proceedings" in IV Jones on Evidence, c. 30, (supplement 1978) 327 .

65. Id. at 328. 


\section{Extrinsic Evidence}

In the face of its broad discretion as to the admission of evidence, a board must be particularly cognizant of its duty to be fair to the participants. Fairness does not exist in fact or in appearance where a broad spectrum of evidence is admitted, but then ignored in favour of extrinsic evidence or factors or information gathered by the tribunal itself or its staff and not made public to the participants. A fundamental tenet of the audi alteram partem rule is that a party to an administrative proceeding must have a fair opportunity of speaking to and contradicting information which may be prejudicial to his position. Such opportunity does not exist where the board makes a decision on the basis of political pressures or its own studies - a party cannot controvert that of which he is not aware. ${ }^{67}$

The courts have held that a board will be subject to judicial review if it relies on matters extrinsic to the hearing. ${ }^{68}$ However, it is not entirely clear in law that a party must be given an opportunity to make an adequate reply to an internal document prepared by the staff of the tribunal which may contain allegations against his interests. ${ }^{69}$

\section{Rule 27 of the Rules of Practice of the ERCB reads as follows: ${ }^{70}$}

Where in the opinion of the Board or its staff it is proper for the applicant to be made aware of the views of the Board's staff, a submission by a Board staff member may be filed and presented at the hearing in accordance with the provisions of these rules applicable to submissions of intervenors.

This specific provision for evidence of Board staff appears to be seldom used. The staff does make submissions more frequently in hearings conducted by examiners (which are often adjudicative proceedings). ${ }^{71}$ Submissions to full Board hearings are rare, although the staff did appear at the recent inquiry into the ultimate reserves of gas in Alberta and the Alberta gas supply protection formulae (presumably part of the advisory function). ${ }^{72}$ However, it seems somewhat capricious that other participants in a hearing can only be made aware of the views of the Board staff if the Board or its staff see fit to permit that to happen. The staff cannot be required to appear by an applicant or intervenor even though the views of the staff as expressed in camera to the Board may be determinative of the issue involved in the hearing. ${ }^{73}$ However, the ERCB is somewhat more open than the NEB in this regard since the NEB has no provision for evidence by the staff, whether voluntary or not.

There is no doubt in law that a tribunal which is composed of experts in a field is entitled to refer to and derive inferences from its own general

66. Supra n. 62 at 488,94 .

67. Rozander and Groeneveld v. ERCB and Calgary Power L td. (\$2)(1978) 13 A.R. 479 at 485 (Alta.S.C., App. Div.).

68. Id, see also Kanda v. Government of Malaya [1962] A.C. 322, 335-8.

69. A. Roman, "Regulatory Law \& Procedure" in The Regulatory Process in Canada, supra n. 2 at 83.

70. Supra n. 53.

71. Application No. 780108, Application by Caribe Holdings Ltd. re Application of Zone Designation No. 151 and No. 187-A to parts of Township 27, Ranges 15 and 16, W4M.

72. ERCB Proceeding No. 780491; the report from this proceeding is still pending.

73. An application for a direction from the ERCB that the staff be required to file a submission and appear for cross-examination was recently denied by the ERCB. (Proceeding \#780242, Amerada Minerals Corporation of Canada Ltd., Application for Permit to Construct a Sour Gas Line in the Chestermiere - Okotoks Fields, June 19, 1979). 
knowledge in that field ${ }^{74}$ Further, there is some authority that a tribunal is entitled to rely upon information obtained otherwise than in evidence in a hearing, particularly where the tribunal is exercising a broad discretionary or public policy decision-making function and is not required to hold a hearing. ${ }^{75}$ Even tribunals making essentially judicial decisions or adjudicating specific questions of fact, and whose decision-making process is essentially confined to a hearing, are occasionally permitted to obtain information otherwise than through evidence adduced at the hearing. ${ }^{76}$ However, if the decision-making process is essentially confined to a hearing, natural justice requires that the tribunal disclose information to the parties and give them an opportunity of meeting it where the information is being relied upon by the tribunal. ${ }^{77}$ This is particularly so where there is uncontradicted evidence at the hearing to the contrary.

In Seafarers' International Union v. $C N R,{ }^{78}$ the Federal Court of Appeal held that there was no duty to disclose to objectors at the hearing all of the expertise or extracurial information relied upon where the tribunal is making a discretionary public policy decision relying on all kinds of accumulated information and expertise and a hearing, though held, was not required to be held. At 379 - 380, LeDain J. stated:

I know of no cases, however, supporting the general duty to disclose all of the material which is to form part of the basis of the decision, including information of which a tribunal may take official notice. It would seem obvious that a tribunal cannot, as a practical matter, be expected to give notice of its own expertise, or in other words, the informed judgment and policy perspectives which are the result of its special qualifications and experience.

However, in Magnasonic Canada Limited v. Anti-Dumping Tribunal, ${ }^{79}$ Jackett C.J. observed at page 1247:

A right of a party to 'appear' at a 'hearing' would be meaningless if the matter were not to be determined on the basis of the 'hearing' or if the party did not have a basic right to be heard at the hearing.

At 1248 - 49, he stated:

We fully accept that the Tribunal may conduct a programme of amassing information relevant to a matter before it. What, as it appears to us, the statute contemplates [in this case, the statute being discussed was the Anti-Dumping Act] is that such material, to the extent that it seems useful, be built into the record of the matter during the course of the hearings in such manner as the Tribunal chooses, provided that it is consistent with giving the 'parties' an opportunity to be heard. (One obvious way is to have commission counsel who submits evidence and makes submissions in the same way as counsel for a party.)

The case held that the Anti-Dumping Tribunal had not conducted the inquiry required by the statute because it had based its decision on information which was not disclosed to the parties.

74. Re Golomb and College of Physicians and Surgeons (1976) 68 D.L.R. (3rd) 25 at 45 (Ontario High Court, Divisional Court). But see Caribe Holdings Ltd. v. ERCB (1978) 13 A.R. 132 (Alta. S.C. App. Div.) in which Morrow, J.A. granted leave to appeal from an ERCB decision. He held that there may be points of law involved where it was unclear if the Board had relied on the knowledge of examiners rather than on views arising from material placed before the examiners.

75. Seafarers International Union v. C.N.R. [1976] 2 F.C. 369 (C.A.).

76. Pfizer Co. v.Deputy M.N.R.[1977]1 S.C.R.456,6 N.R.440,68 D.L.R.(3d)9.

77. Id, see also Magnasonic Canada Limited v. Anti-Dumping Tribunal [1972] F.C. 1239;30 D.L. R. (3d) 118 (C.A.).

78. Supra n. 75.

79. Supra n. 77. 
Chief Justice Jackett repeated this view in Re Canadian Radio Television Commission and London Cable T.V. Ltd ${ }^{80}$ In that case, a hearing was discretionary but was in fact held, at which time the financial statements and projections as to future earnings of the company were withheld from the intervenors. It was held that the intervenors should have been provided with the information to enable them to form a considered opinion as to whether the increase in rates was justified or not. Chief Justice Jackett held that what was contemplated by the statute was a meaningful hearing. He stated: ${ }^{\text {11 }}$

In my view, at the very minimum, what the statute required, by requiring a 'public hearing', was a hearing at which, subject to the procedural rules of the Commission and the inherent jurisdiction of the Commission to control its own proceedings, every member of the public would have a status 'to bring before' the Commission anything relevant to the subject-matter of the hearing so as to ensure that, to the extent possible, everything that might appropriately be taken into consideration would be before the Commission, or its Executive Committee, when the application for the amendment was dealt with. To be such a public hearing, it would, in my view, have had to be arranged in such a way as to provide members of the public with a reasonable opportunity to know the subjectmatter of the hearing, and what it involved from the point of view of the public, in sufficient time to decide whether or not to exercise their statutory right of presentation and to prepare themselves for the task of presentation if they decide to make a presentation. In other words, what the statute contemplates, in my view, is a meaningful hearing that would be calculated to aid the Commission, or its Executive Committee, to reach a conclusion that reflects a consideration of the public interest as well as a consideration of the private interest of the licensee; it does not contemplate a public meeting at which members of the public are merely given an opportunity to tblow off steam'. (emphasis added)

There is some authority for the proposition that the tribunal need not permit examination of material gathered and prepared on its behalf. ${ }^{82}$ However, other cases suggest that the failure to disclose material evidence or information may constitute a denial of natural justice, although it does not always do so. ${ }^{83}$

Any lawyer who has appeared before the National Energy Board or the Energy Resources Conservation Board has seen instances where a particular decision (adjudicative or advisory) at least appears to have been made on the basis of extrinsic factors or board staff studies rather than on the basis of the evidence presented in the hearing. A recent example of this was the inquiry giving rise to the report "Canadian Natural Gas Supply and Requirements - National Energy Board February 1979". Although the hearing arose pursuant to the Board's inquiry powers in discharging its advisory function and was arguably not adjudicative (notwithstanding that the resultant report will have a significant effect on corporations in the oil and gas industry), it seemed to many observers that the NEB may not have reached its conclusions on the basis of the evidence.

80. [1976] 2 F.C. 621, 13 N.R. 292, 67 D.L.R. (3d) 267 (C.A.).

81. [1976] 67 D.L.R. (3d) 267, 270.

82. Re Robinson, Little \& Co. Ltd, and Retail Clerks Union (1975) 60 D.L.R. (3d) 712; [1976] 1 W.W.R.171(B.C.).

83. Re F.W. Woolworth Co. Ltd. and Retaih, Wholesale, etc. Union (1975) 53 D.L.R. (3d) 135 (B.C.) at 141; Re Cypress Disposal Ltd. and Service Employees (1974) 50 D.L.R. (3त) 150, [1975]2 W.W.R. 663(B.C.C.A.); Tichy v.Minister of Manpower and Immigration [1974]2 F.C. 42 (C.A.); Re Basu and Bettschen (1975) 59 D.L.R. (3d) 392,[1975]6 W.W.R. 421 (Sask. C.A.). contra Canada Labour Relations Board v. TransAir Ltd. [1974] 2 F.C. $832 ; 51$ D.L.R. (3d) 709 at 715, note 4; 6 N.R. 123; reversed on other grounds (1976) 67 D.L.R. (3d) 421,9 N.R. 181 (F.C.C.). 
Another example in the NEB sphere is the Interprovincial Pipe Line case, where a hearing was held, followed by the approval of the extension of the pipeline from Sarnia to Montreal. ${ }^{84}$ All this occurred after the federal government had publicly indicated that the extension was considered to be of great national importance.

Similarly, would it have been reasonable to expect the ERCB to refuse industrial development permits for the Alberta Gas Ethylene plant at Red Deer and the derivative petrochemical plants when the provincial government had already publicly adopted a policy of up-grading Alberta's natural resources within the province? ${ }^{85}$

The great concern about the failure of a board to make its decisions on the basis of evidence heard in the hearing is that the doctrine of fairness either does not appear to be applied or is not in fact applied. There should be no lack of public confidence in the impartiality of adjudicative agencies, particularly where such agencies are enjoined to have regard to the public interest. ${ }^{86}$

It has been suggested that the creation of tribunals is an attempt by government to govern in a non-departmental way. ${ }^{87}$ If this were so, it would follow that people should accept that decisions of administrative tribunals are made on the basis of political expediency and evidence extrinsic to the hearing. The Canadian concept of an administrative tribunal may be that it is an extension or an alternative to a department of government, but Canadian lawyers and judges tend to view tribunals as more or less similar to courts. To the legal mind, a tribunal is much more than just a part of the process of government. ${ }^{88}$ In the Crowe case ${ }^{89}$ Chief Justice Laskin of the Supreme Court of Canada stated in reference to the $\mathrm{Na}$ tional Energy Board:

What must be kept in mind here is that we are concerned with a Section 44 application in respect of which, in my opinion, the Board's function is quasi-judicial or, at least, is a function which it must discharge in accordance with the rules of natural justice, not necessarily the full range of such rules that would apply to a court (although I note that the Board is a court of record under Section 10 of its Act) but certainly to a degree that would reflect integrity of its proceedings and impartiality in the conduct of those proceedings. This is not, however, a prescription that would govern an inquiry under Section 14(2) and 22.

Similarly, in England, Lord Franks' Committee came to the conclusion that tribunals are not part of the administrative machinery of government under the control of departments but are part of the judicial system under the rule of law..$^{90}$

84. See National Energy Board Report to the Governor in Council. "In the Matter of the Application under the National Energy Board Act of Interprovincial Pipeline Limited" (May 1975).

85. See eg. ERCB Report 75-N. "In the Matter of Application of the Alberta Gas Ethylene Company Ltd. et al under Section 42 of the Oil and Gas Conservation Act".

86. Committee for Justice and Liberty, Consumers A ssociation of Canada, Canadian Arctic Resources Committee v. The National Energy Board, Canadian Arctic Gas Pipeline Limited and the A ttorney General of Canada et al (the "Crowe case")[1978]1 S.C.R. 369 per Laskin, C.J.at 391.

87. A. Roman, "Regulatory Law and Procedure" in The Regulatory Process in Canada, supra n.2,68 at 74 .

88. Id.

89. Supra n. 86 at 385.

90. Report of the Committee on Administrative Tribunals and Enquiries (Cmnd. 218, 1975). See discussion of this in Lord Denning, The Discipline of Law (1979), 83 et seq. 
The logical conclusion is that the energy boards should not make decisions on the basis of staff advice or staff studies which are not presented in evidence at a hearing, particularly where the tribunal is exercising functions which can be construed as adjudicative. A decision based on such information is contrary to the rules of natural justice. Yet it appears that decisions are being made every day on the basis of extrinsic evidence of this nature, or on the basis of political influence. This renders the hearing process largely superfluous and minimizes the effect of the role played by lawyers as counsel.

\section{Cross-examination}

The most public role of lawyers in the hearing process is the conduct of cross-examination. There is no general right to cross-examination recognized by the common law but any party affected should be allowed to cross-examine on evidence against his interests, at least if there is no other way in which the information can be obtained..$^{91}$ In the absence of pre-hearing discovery, cross-examination is essential to ensure fairness.

One often hears that cross-examination by lawyers is inappropriate in the context of technical hearings. The view has been expressed that cross-examination should not be used as a general rule because it slows down what are intended to be expeditious proceedings. It has also been suggested that the elimination of cross-examination would benefit intervenors since witnesses for regulated industries are better able to withstand such cross-examination..$^{92}$ Another approach would permit cross-examination but not by lawyers. ${ }^{93}$

A great deal of cross-examination could be eliminated from the hearing process. Much of it is technical and should be resolved between experts outside the hearing room. A technique apparently now being used with effectiveness is the post-hearing meeting which follows most hearings of the Energy Resources Conservation Board. In such meetings, the staff of the applicant meet with the staff of the Board to resolve technical issues. There has not as yet been a question about the right of intervenors to participate in those technical meetings, although the matter was raised but not resolved at a pre-hearing conference prior to the recent application by PanAlberta Gas Ltd. for a permit authorizing removal of gas from the province of Alberta. ${ }^{94}$

Complete elimination of cross-examination would be the last step in making administrative proceedings completely political. The right of cross-examination is fundamental to the concept of natural justice and must be retained. Lawyers are trained in the art of cross-examination and should be able to perform the function effectively, provided that they learn the subject area sufficiently well.

The greatest problem with cross-examination is not the delay it entails but the fact that in the current hearing process it appears to have no ef-

91. Toronto Newspaper Guild v. Globe Printing Co. [1953] S.C.R. 18; The Administrative Procedures Act R.S.A.1970, c.2, s.6.

92. The Conduct of Hearings by Federal Administrative Agencies, supra n. 5 at 72.

93. R. Gibbs, D. MacFarlane and H. Knowles, "A Review of the National Energy Board Policies and Practices and Recent Hearings",(1971)9 A lta. L. Rev. 523,547.

94. ERCB Application No. 780640, In the Matter of the Gas Resources Preservation Act; and In the Matter of an A pplication by Pan-Alberta Gas Ltd. for a permit authorizing the removal of gas from the province of Alberta; Pre-Hearing meeting January 17, 1979. 
fect on the decision being made. Many lawyers appearing as counsel before a tribunal have succeeded in conducting what they feel to have been an effective cross-examination, only to realize that the effect was lost on the board members. At least part of the reason for this is the absence of lawyers as board members. Non-lawyers do not view crossexamination in the same manner as those who have practised law. They often appear to be overly sympathetic to the less impressive witness who has been "tricked" by a "crafty" lawyer.

The major source of membership for many Canadian tribunals is the public service. ${ }^{95}$ Board members are frequently appointed from the staff of the board. Five of the seven current members of the Energy Resources Conservation Board have risen through its staff. The same syndrome is present to a lesser extent in the NEB, where a majority of the current members have been in public service prior to appointment. In addition to encouraging the viewpoint that Canadian regulatory tribunals are really another branch of public service with specialized duties, the appointment of former public servants makes it difficult for a government to refuse to reappoint them, as this may be seen as tantamount to firing public servants. ${ }^{96}$ In his study of regulatory law and procedure, Andrew J. Roman states: ${ }^{97}$

The practice of appointing a large number of former public servants, frequently without any business or adjudicative experience, has profound implications for the quality and style of decision-making by these boards. If a large part of the rationale for the use of an administrative tribunal rests on the expertise found among the members of the tribunal, drawing such members from the public service (which has a number of knowledgeable generalists but few real experts) rather than from experts within the industry somewhat undermines the argument. This, coupled with the relatively limited number of staff experts available to Canadian regulatory tribunals (in comparison with the depth of expert resources available to the regulated industries) suggests that the description of Canadian tribunals as possessing significant expertise to apply to their decisionmaking processes is largely mythical. If part of the reason why courts and ministers are reluctant to overrule tribunals is that they feel that they lack the expertise of tribunals, perhaps a closer look at just what level of expertise tribunals really do have might dissipate some of this reluctance.

At page 91 he observes: ${ }^{97}$

Given the relatively low levels of tribunal staff salaries and the small staff of Canadian tribunals, the assumption of expertise exceeding that of the participants is probably contrafactual.

One view is that members of boards and their senior staff may be a major source of weakness in the regulatory process because of being closely associated with the public service. ${ }^{98}$

If $\mathrm{Mr}$. Roman is right, and if effective cross-examination would have a greater impact if more lawyers were Board members, it follows that both the appearance and actuality of fairness would be emphasized by the appointment to administrative tribunals of more persons with legal training and tribunal experience.

\section{Political Influences on Tribunals}

The effectiveness of lawyers in the hearing process is greatly influenc-

95. C. Andrew and R. Pelletier, "The Regulators" in The Regulatory Process in Canada, supra $\mathrm{n} .2$ at 147.

96. A. Roman, "Regulatory Law and Procedure" in The Regulatory Process in Canada, supran. 2,68 at 77 .

97. Id.

98. W. Stanbury, "Executive Summary: Studies on Regulations in Canada" in Studies on Regulation in Canada, (ed. W. Stanbury, 1978) 4; G. Reschenthaler, "Direct Regulation in Canada: Some Policies and Problems", id 37 at 60 - 61. 
ed by the fact that the ERCB and the NEB perform both advisory and adjudicative roles. The advisory duties under Part II of the NEB Act have been recognized as problematical by Board members, staff and representatives of participating interests. ${ }^{99}$ Similar views exist in respect to the ERCB, but to a lesser extent.

As noted above, the advice function was included in the NEB Act since there was no other government department responsible for energy matters at the time. However, since the Department of Energy, Mines and Resources was created in 1966, its advisory functions have substantially overlapped that of the NEB. It is understood that there is substantial competition between the NEB and EMR with respect to the advisory role, and that the importance of the NEB as an advisory body is waning. ${ }^{100}$ The Department of Energy, Mines and Resources has very extensive capacities in every aspect of energy affairs of the country and has become, in practice, the chief advisor to the government on energy policy.

Existence of the advisory function has a profound effect on the approach of a board to its adjudicative function. The effect was succinctly expressed by Professor A.R. Lucas in his study of the NEB: ${ }^{101}$

Advisory functions absorb a substantial part of the time of some board members. It appears that most of these duties are handled by an elite group consisting of the chairman and the more senior members, as well as some members who have specialized knowledge in particular areas. A considerable amount of status within the board appears to derive from participation in ministerial advice and inter-departmental policy advice activities. A good deal of apparent power is associated with personal success in this advisory role.

He also noted: ${ }^{102}$

In a National Energy Board member, success in mastering the advisory role may profoundly affect the member's ability to carry out adjudicative regulatory functions in a completely impartial manner. In considering applications, his instinct would be toward the 'politically viable decision', if more general policy considerations were involved. In any event he would probably already have played a role in providing advice to government on these more general policy issues. Sometimes, as in the case of the Interprovincial PipeLine Sarnia - Montreal extension, the subject of the application is itself the previously discussed matter of general government policy.

Concern has therefore been expressed by representatives of many of the interests that participate in board proceedings that the importance, and indeed the very nature of adjudicative proceedings are materially affected by the advisoryaduties of board members. It is said that the board is likely to make decisions based on members' "political insights' even when there is no suggestion of direct or indirect consultation with the minister on a particular application; and further, that board members see nothing wrong with the situation because they tend to judge their behaviour by the standards of public-service policy advisors rather than those of quasi-judicial decision-makers. All agree that the widespread suspicions generated are extremely damaging to the board's credibility as an adjudicatory agency. This in turn may reduce public as well as industry confidence in the board and impair its ability to carry out its functions effectively.

If the advisory function tends to make the decision political rather than adjudicative, the hearing process is pointless and any legal involvement has failed to ensure fairness.

99. A. Lucas, "The National Energy Board" in The Regulatory Process in Canada, supra n. 2,259 at 267 et seq.

100. Notwithstanding this development, the NEB is still considered by many to be a political entity, viz. the position of Premier Lougheed of Alberta expressed at the First Ministers' Conference in January 1979 that the NEB should be restructured as a truly national agency by permitting provincial as well as federal appointments. For a more complete discussion of the advisory role of the National Energy Board, see A. Lucas, id at $267-270$ and I. MacDougall, Supre n. 6 at 339 - 341.

101. A. Lucas, id, at 269.

102. Id at 270. 
The concept of political accountability has the effect of reducing political influence on the hearing process while maintaining government control. This concept currently exists in respect to various functions of the NEB and the ERCB. With respect to the export of natural gas and petroleum and petroleum products, the NEB Act provides that the board has final authority, although by regulation the decisions with respect to export of natural gas have been made subject to confirmation by the Governor-in-Council. The Board can vary certificates or orders or licences it has issued only with confirmation of the Governor-in-Council. ${ }^{103}$ This often results in conflict with the Department of Energy, Mines and Resources. Decisions relating to the export of crude petroleum and oil products as opposed to natural gas are free of government approval. A certificate to build a pipeline, however, requires confirmation by Orderin-Council, although there is nothing in the legislation which permits the Governor-in-Council to alter or vary a certificate that the Board has indicated it is prepared to issue. Consequently, if the Board decides to issue a certificate to an applicant to build the pipeline subject to certain conditions and terms, the government can accept or reject the certificate, but not alter it. There is no provision in the National Energy Board Act for a decision of the National Energy Board in respect of tariffs to be confirmed by Governor-in-Council, or to be changed by the government or referred to the government.

One instance where the ERCB is subject to some governmental control relates to the issuance of permits to construct pipelines under The Pipeline Act, 1975. The application for a permit or an amendment of a permit must be referred to the Minister of the Environment and the Minister of Energy and Natural Resources for their approval of the application as it affects matters of the environment. ${ }^{104}$ Industrial development permits granted under the Oil and Gas Conservation Act require cabinet approval. ${ }^{105}$ The result of such provisions is to provide political accountability where the tribunal is exercising an adjudicative function.

\section{THE SUGGESTED ROLE}

Having outlined some of the apparent faults of the current system, it remains to consider what steps can be taken to rectify them. The essence is that the process must not only be fair but appear to be fair. The role of the lawyers should be to ensure that the concept of fairness of administrative tribunals is present in form and actuality. The current prominent role of lawyers as counsel perhaps creates an impression of fairness through the apparent application of the rules of natural justice. However, that impression will continue to be misleading until the process is reformed to create actual fairness in the form of judicial rather than political decisions.

It is hard to believe that adjudicative fairness can be achieved while the tribunal has a concurrent duty to advise politicians. The advisory role should therefore be divorced from the adjudicative role. In respect to the NEB, the advisory role could simply be removed from the Act and left to the Department of Energy, Mines and Resources, thereby eliminating a

103. National Energy Board Act, S.C. 1959, c. 46, s. 17.

104. The Pipeline Act, 1975, S.A. 1975, c. 30, s. 8.

105. Oil and Gas Conservation Act, R.S.A. 1970, c. 267, s. 42(3). 
great deal of duplication as well as interdepartmental rivalry. The $\mathrm{Na}$ tional Energy Board would be left to act as a national energy court having adjudicative responsibilities in respect to certificates of public convenience and necessity, export licences and rates, tolls and tariffs. Similarly, the ERCB could be divided into an advisory agency and an adjudicative agency.

The proceedings should not be strictly bound by the rules of evidence but decisions of the energy courts should be made only on the evidence presented in the hearing. The staff of the court should be completely separated from the court itself and should have no influence other than in the presentation of evidence in the hearing. Staff would, of course, be subject to cross-examination on that evidence. Such a system would be somewhat similar to that which currently exists in the Federal Energy Regulatory Commission in the United States. The agency staff members who work on a particular case are required to represent the public interest and are precluded from speaking in private to the administrative law judge or to the commissioners. This should have the effect of enforcing the doctrines of fairness by allowing each party the opportunity to controvert all evidence upon which the decision may be made. Only then can the hearing be "meaningful". Provided that the decision is made on the basis of the evidence at the hearing, the lawyers' role as counsel to the parties and to the board will be of fundamental importance.

Board counsel should have greater involvement. Through submission of evidence and cross-examination, they should accept and discharge a duty to see that the applicant in adjudicative proceedings brings its case within the confines of the applicable statute, or that an advisory proceeding hears all requisite evidence. In argument, they should take a position supported by the evidence.

Lawyers with knowledge in the art of cross-examination and with experience in the oil and gas area should be appointed as members of the boards. They would bring an increased awareness of the rights of the individual and an appreciation of the principles of natural justice which could only benefit the impartiality of the proceedings. Such appointments would also follow the American model, where more and more lawyers are being appointed as administrative law judges. Similarly, since the Franks Report, most chairmen of tribunals in the United Kingdom are qualified lawyers. ${ }^{106}$ There is no more need to have financial or engineering experts as board members than to have specialized judges in courts.

If political control of the energy boards is seen as desirable, it can be retained by requiring executive approval of decisions in appropriate cases. Honesty is required in the regulatory process. If the issue is important enough to require political control, then the decision should be made at the political level and not by a tribunal subject to behind-the-scenes political influence. If the people dislike the result they can exercise their democratic right to remove the government at the next election. It is reprehensible to put a judicial facade over a political decision in order to make the decision appear impartial.

Perhaps it is predictable for a lawyer to suggest that the first step toward regulatory reform should not be to kill all the lawyers. The first 
step should be to establish more effective participation by lawyers in the hearing process, which would result in a system that is fairer to the participants. It is always more expensive and time consuming to reach a fair decision than an unfair decision; but if the only price for equity is some expense and delay, isn't it worthwhile? 